\title{
エンジン開発における可視化適用事例の紹介*
}

\author{
森田＼cjkstart照義**

\section{Application of optical measurement for engine development}

Teruyoshi Morita

\section{1. 緒 言}

近年，地球温暖化やそれに伴う気候変動が大きな問題 となっている，また，石油の枯渴問題，中国やインド等 の BRICsをはじめとする国々での自動車保有台数の増 加を背景として CO 2 低減が大きく求められている。こ のような背景のもと, 自動車に対する, 燃費規制, 排出 ガス規制は年々厳しさを増しており，世界中の自動車 メーカーが新しい技術開発を行っている，今回は，この ような技術開発において，エンジン筒内可視化計測を用 いた事例を紹介する。

\section{2. エンジン技術の進化}

ガソリンエンジンでの CO 2 を低減する手段として, リーン燃燒が挙げられる。 Fig. 1 に本田が開発してきた リーン燃焼技術の進化を紹介する。1970 年代, 最も厳 しいとされた排ガス規制マスキー法に対応するため, CVCC (Compound Vortex Controlled Charge) 方式 の開発から始まり，近年では直噴技術や電子制御技術の 進化により, DISC (Direct Injection Stratified Charge）燃焼方式を開発してきた。

DISC 燃焼方式は 1995 年頃から登場し始めたが，第 1 世代と呼ばれるウォールガイド式では，燃焼室内に直 接噴射された燃料噴霧を，ピストン壁面を使って点火プ ラグに導く方式で，壁面により混合気が保持されて良好 な着火性が確保される反面，壁面付着した燃料により， $\mathrm{HC}$ 排出量が増加するという課題があった。これに対し, 第 2 世代と呼ばれるスプレーガイド式では壁面を使わず に, 燃料噴霧を直接点火プラグ近傍に導く混合気形成を 行う。この方式では壁面付着が少なく $\mathrm{HC}$ 排出量の低 減が可能であり, 燃焼コントロールの自由度が改善され る事から Fig. 2 に示すように大きな燃費改善効果が期 待される。

しかし，混合気を保持する壁面が無いため，着火性の

* 原稿受付 2010 年 4 月 23 日

** 株式会社 本田技術研究所四輪 R\&D センター （干 321-3393 芳賀郡芳賀町下高根沢 4630 番地, E-mail : Teruyoshi_Morita@ n.t.rd.honda.co.jp)
確保が課題であり，混合気を機械的なガイドが無い状態 で適切に点火プラグに導く事が必要となり，インジェク 夕噴霧に要求される特性や噴射制御がより高度になる。

前述のように，スプレーガイド式では燃料噴霧を直接 点火プラグに導く必要があり, 燃料噴霧の挙動そのもの が着火性や燃焼に大きく影響する。実際のエンジンにお いては, 圧力変化, 温度変化, 筒内流動など多くの外乱 要因がありこれらの影響を考慮した上でインジェク夕噴 霧や燃焼室形状などを設計する必要がある。今回は，ス プレーガイド式 DISC 燃焼の実際の開発において, LIF

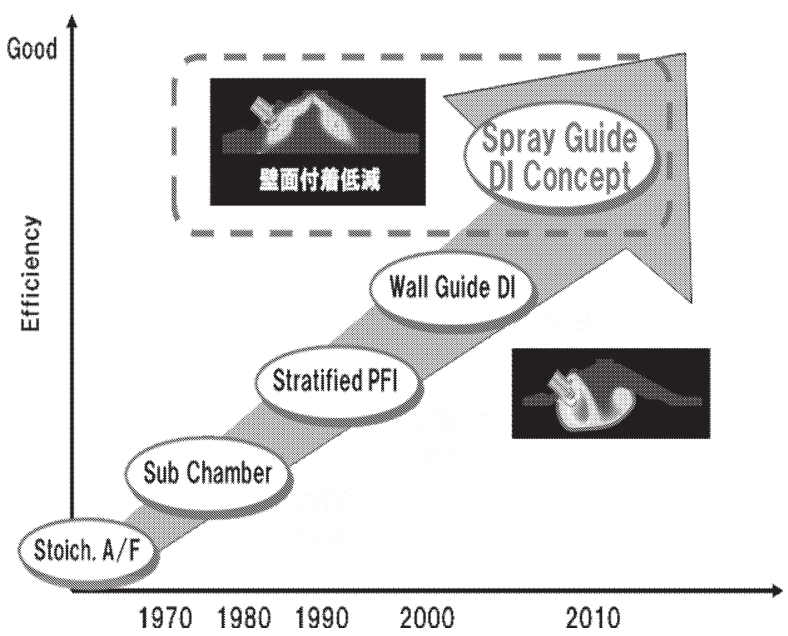

Fig. 1 Transition of gasoline lean burn technology.

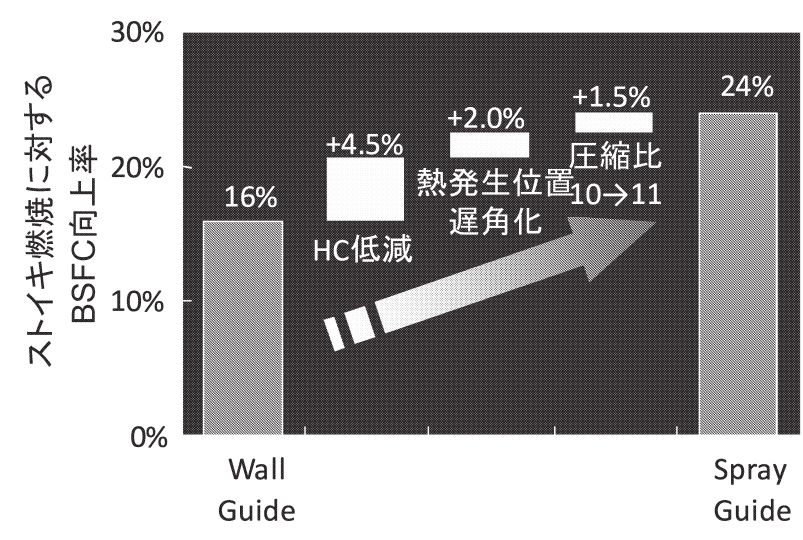

Fig. 2 Improvement by sprayguide DI. 
(Laser Induced Fluorescence) 法や LIEF (Laser Indeced Exciplex Fluorescence) 法を適用した解析事例 を紹介する。

\section{3. 実験装置・方法}

計測は，Fig. 3 に示すようなべースエンジンに基づい た，Fig. 4 に示す可視化エンジンを用いた。直噴イン ジェクタはペントルーフの中央付近，点火プラグは 2 つ

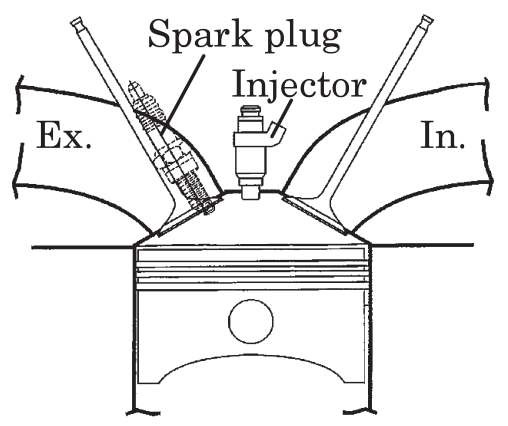

\begin{tabular}{|c|c|}
\hline Engine type & DOHC 4valve \\
\hline No. of cylinders & 1 \\
\hline Bore $\times$ Stroke & $86 \mathrm{~m} \mathrm{~m} \times 86 \mathrm{~mm}$ \\
\hline Displacement & $499.6 \mathrm{cc}$ \\
\hline Comp. ratio & 11.0 \\
\hline Valve dia. / lift & $\begin{array}{c}\text { In. } 34 / 9.8 \mathrm{~mm} \\
\text { Ex. } 28 / 9.7 \mathrm{~mm}\end{array}$ \\
\hline
\end{tabular}

Fig. 3 Engine specification.

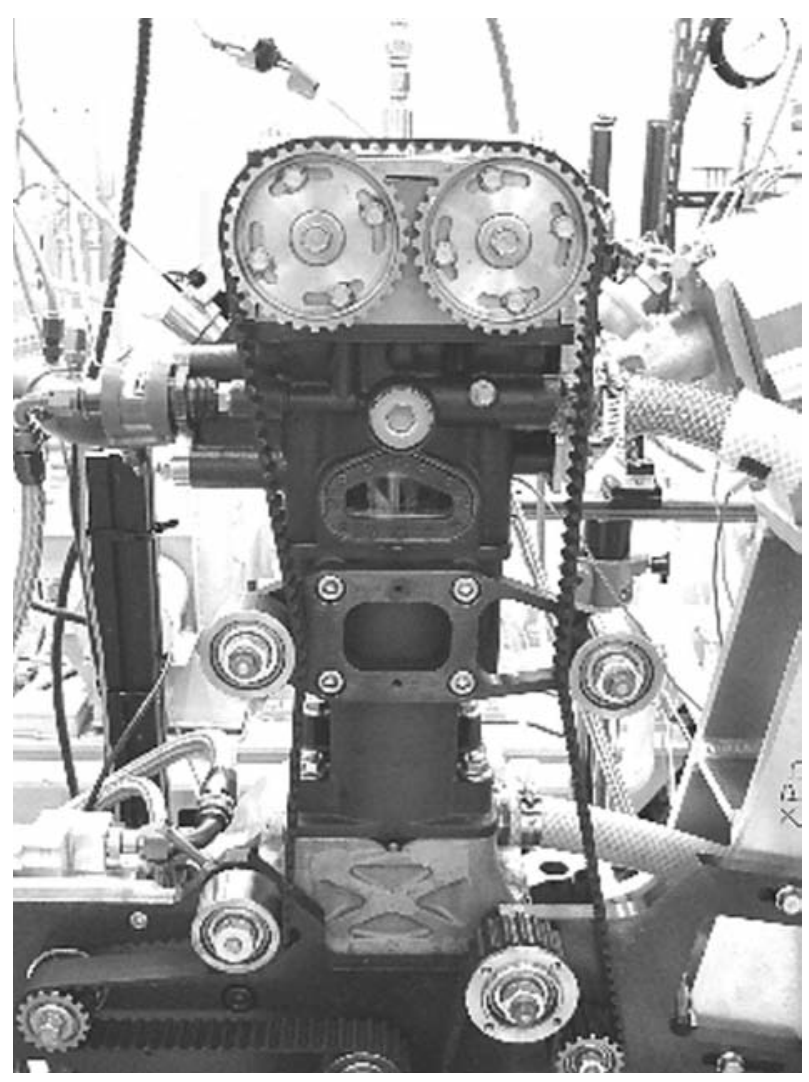

Fig. 4 Optically-accessed engine.
の排気バルブ間に配置している。直噴の燃料圧力は 10 $\mathrm{MPa}$ とした。

Fig. 5 に可視化エンジンにおける観測視野を示す。観 察空の取り付け部が必要なため，観測可能な範囲はエン ジンのボア $\phi 86$ に対し幅で $60 \mathrm{~mm}$ 程度となっている. また，実験に用いた直噴インジェク夕は Fig. 6 に示す ようなピントルノズル構造を, 単体での噴霧は Fig. 7 に示すフォームを持つ.

この噴霧の特幑は，噴射時期の筒内圧力条件により， フォーム変化が発生する事で, 実際のエンジンでは様々 な運転条件の下，燃料噴霧を確実に点火プラグに導く事 が必要になる。参考として，Fig. 8 にインジェクタ単体 での背圧違いでのフォーム変化の Mie 散乱画像を示す. 背圧 $1 \mathrm{MPa}$ では，噴射後，噴霧が巻き上がる挙動を示 している。スプレーガイド式 DISC 燃焼では多くの場合, この現象を利用し適切な空燃比，気化特性，流速となる

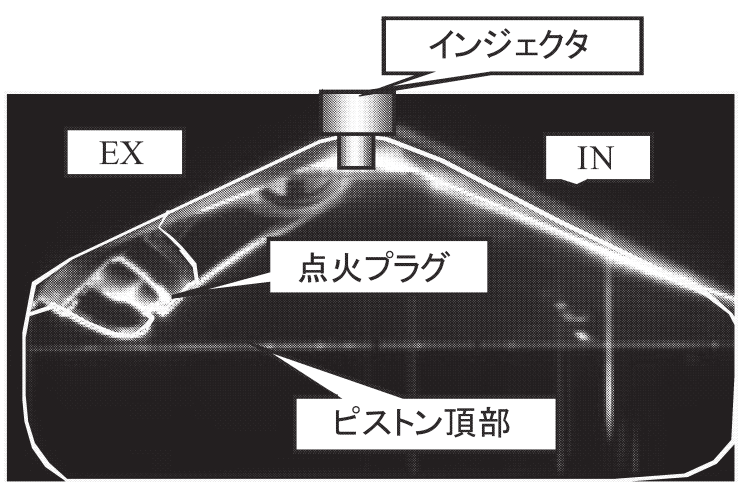

Fig. 5 Visible area of Optically-accessed engine.

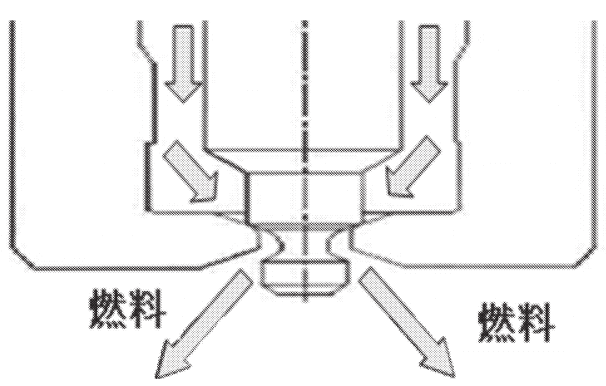

Fig. 6 Schematic of injector nozzle.

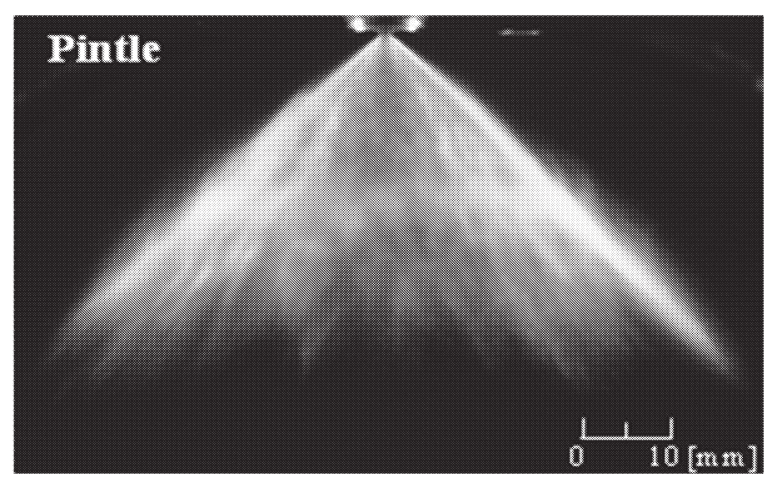

Fig. 7 Spray form. 


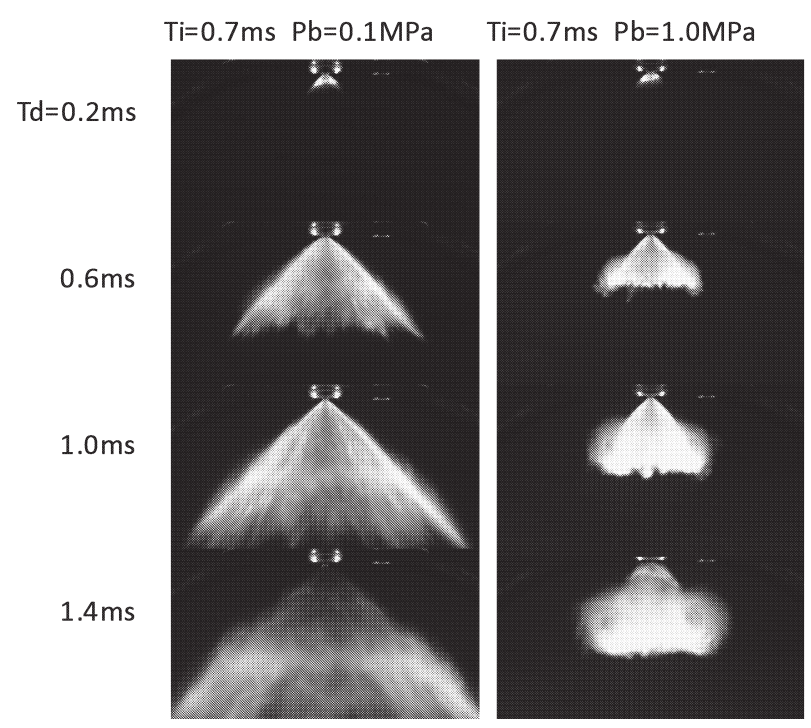

Fig. 8 Comparison of spray form between different back pressure.

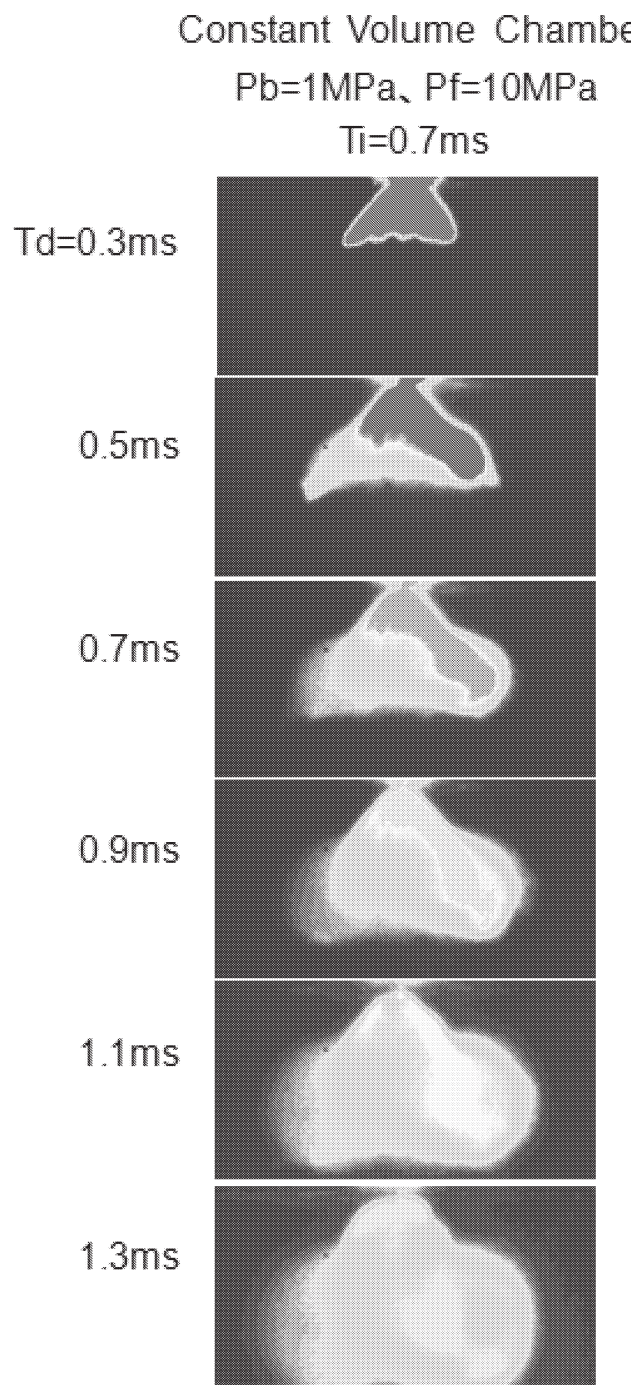

ような位置に点火プラグが配置されている。

\section{LIF による混合気分布評価}

通常のエンジン開発では，インジェクタの単体評価を 行った後，実機試験を行うが，スプレーガイド式 DISC 燃焼方式の様な筒内流動や温度等による影響を受けやす い場合には，インジェクタ単体評価のみでは十分な設計 指針が得られない場合が発生する。高圧容器での単体噴 霧計測では，通常 Mie 散乱で燃料噴霧のフォーム形状， ペネトレーションなどの評価を行っているが，上記のよ うな課題に対応するため，単体評価を高温・高圧で行う 場合がある。この場合，Mie 散乱のみの液滴分布では 混合気全体の挙動評価はできず，ここでは実機との噴霧 挙動比較を行う目的で LIF 法を適用し, 気液相全体の 評価を行った。

Fig. 9 に単体容器および, 可視化エンジンでの LIF 画像を示す。単体容器ではレーザーを図の右方向から入 射しており，可視化エンジンでは下方向から入射してい る。単体と実機では，噴霧形状が異なっていることが分

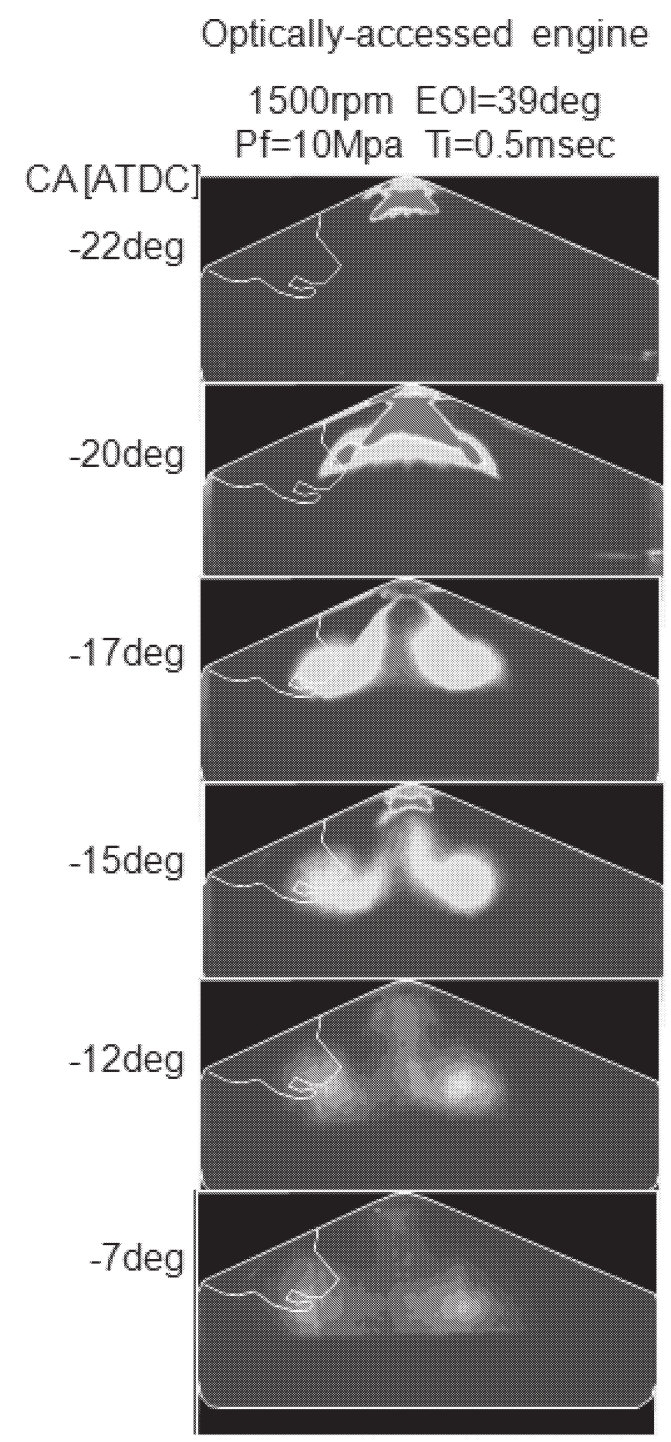

Fig. 9 Comparison of LIF result between constant volume chamber and optically-accessed engine. 


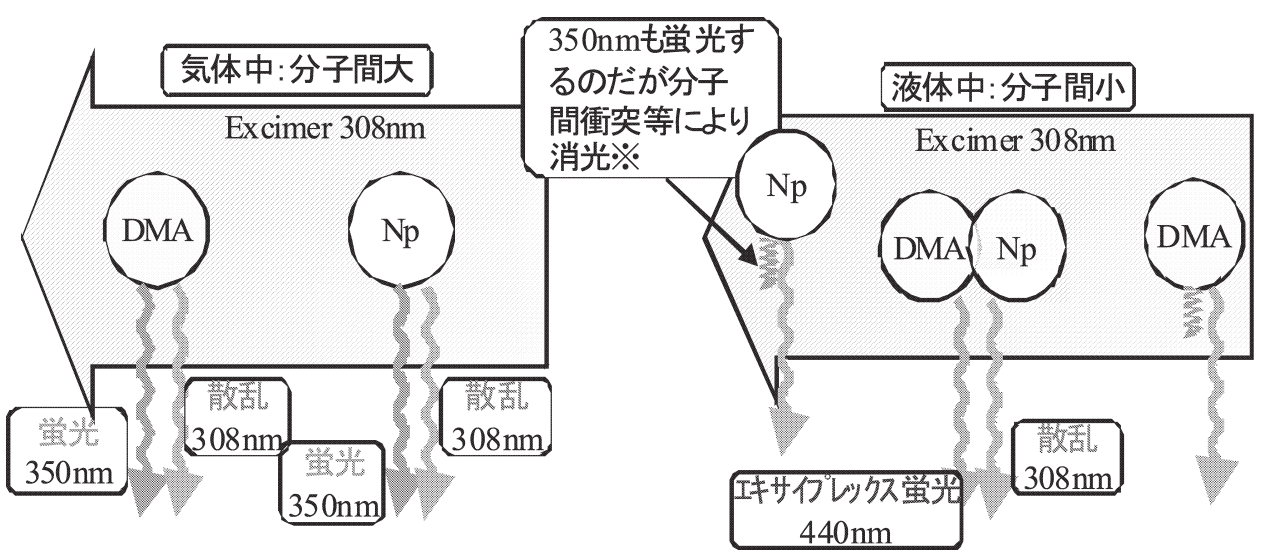

Fig. 10 Exciplex system of Naphthalene/DMA.

かる.

高圧容器では，背圧が一定であり，ほぼ対象な噴霧形 状を維持しているが，可視化エンジンでは噴霧が点火プ ラグ方向に流されている様子が観察できる，実際のエン ジンではピストンの圧縮により圧力・温度が変化すると ともに，筒内流動の影響が大きい，特に良好な着火を得 るためには，実機での噴霧挙動を把握した上で，適正な 位置に点火プラグを配置する必要がある。

\section{LIEF 法による混合気分布解析}

スプレーガイド方式のような直噴による成層燃焼では, 着火性や初期燃焼部分がその後の全体の燃焼を決めてし まうと言っても過言ではない。着火を大きく左右する点 火プラグ近傍の空燃比や燃料の気化状態は，必要な点火 エネルギーや層流燃焼速度による初期燃焼への影響の観 点から十分把握されている必要がある。このような目的 から，LIEF 法による蒸発特性解析を行った。

解析を行うにあたり，蛍光剤はLeach らの研究を参 考にナフタレン (以下 $\mathrm{Np}$ ) と N.N.ジメチルアニリン （以下DMA）を選択した1). Fig. 10 にエキサイプレッ クス蛍光模式図を示す。

DMA とナフタレン（Np）は紫外レーザーでそれぞ れ励起される。分子間距離が離れている気体中では DMA，Np はそれぞれ独立で $350 \mathrm{~nm}$ の监光波長を出し ながら基底状態に戻る。分子間距離の小さい液相中では, 励起された状態で両者が反応し $[\mathrm{DMA}+\mathrm{Np}]+$ というエ キサイプレックス錯体を形成する。 $[\mathrm{DMA}+\mathrm{Np}]+$ は元 のエネルギー準位に戻る際，440 nm をピーク波長とす る蛍光をする。エキサイプレックス錯体にならなかった DMA と Np も多少存在し $350 \mathrm{~nm}$ の光を蛍光するが, 液相中という高濃度場では分子間衝突のエネルギーに費 やされ蛍光はほとんどない.

以上の原理から得られる Np と DMA から生じる蛍光 波長分布および分光に用いたフィル夕特性を Fig. 11 に 示す。液相からの蛍光と気相からの蛍光はピーク波長こ そ離れているが, お互いの蛍光域がオーバーラップして いる。これは気相・液相共に他方の影響を幾らか受ける

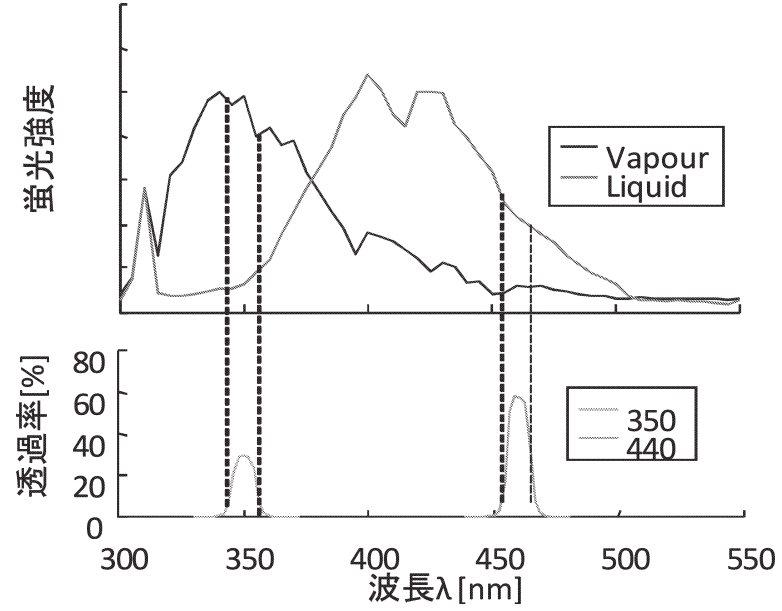

Fig. 11 Fluorescence spectra and transmission spectra of optical filter.

ことを意味するが，インジェクタの噴射時期違いや噴射 率違いが燃料の蒸発拡散に与える影響を相対評価で把握 するには十分な精度が得られると考える.Fig. 12 に光 学システム図を示す。

Fig. 13 にLIEF 法で得られた液相・気相および比較と して LIF 法により得られた画像を示す. Fig. 14 に Fig. 13 における 3 者の平均輝度を示す. LIEF 法により得ら れる蛍光強度は LIFで得られる蛍光強度に比べ低い. これは気液分離分光フィルタによる透過減衰と圧力依存 性の影響を強く受けているからである。そのため, LIEF 法は LIF 法に比べ蛍光強度から AF（空気一燃料 割合）推測精度はさらに低くなるので，液相・気相が存 在する領域変化を評価するのが現状では適切な使用方法 と考える。また，圧力依存を受けない蛍光剤の選定や光 学系の感度を上げる手法等についても本計測法の今後の 課題である.

Fig. 15 にスプレーガイド方式 DISC 燃焼の気相・液相 の時間変化 LIEF 画像を, Fig. 16 に Fig. 15 における気 相/液相面積比率の時間変化を示す。燃料の噴射時期は 噴射終わり上死点前 $45 \mathrm{deg}$.である。燃料噴射開始後 5 deg.では気相，液相ともに噴霧が観測されているが，噴 


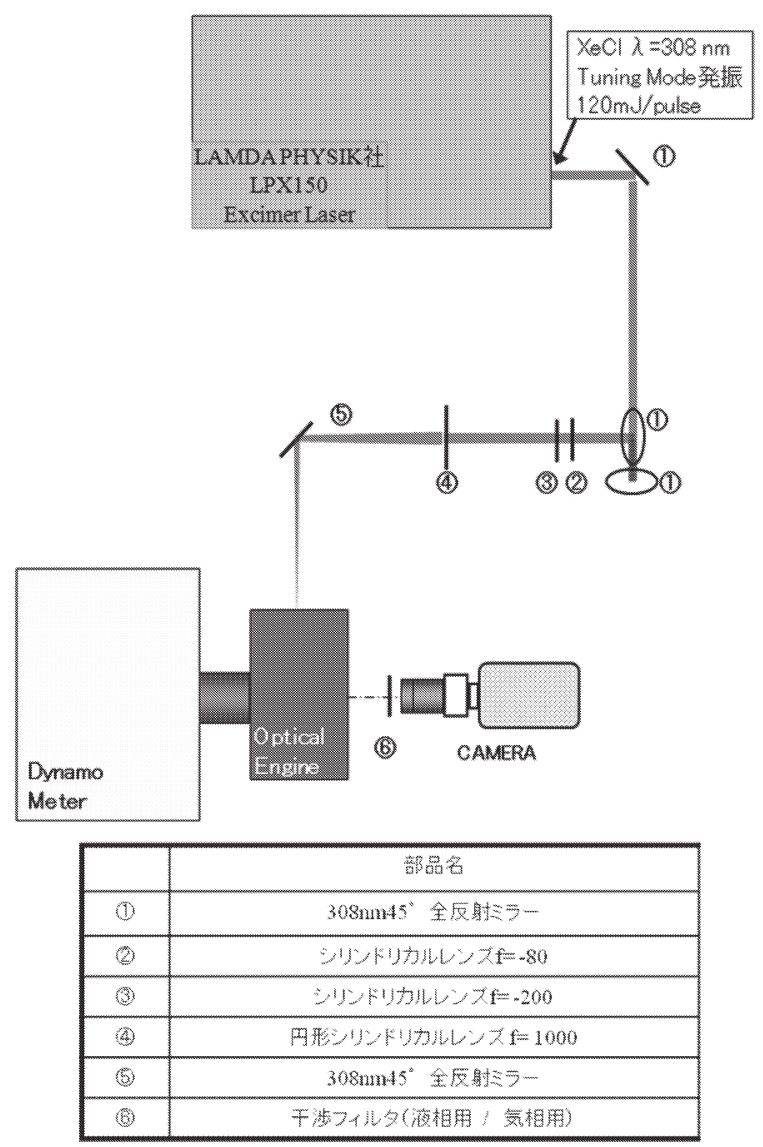

Fig. 12 Instruments of LIEF.

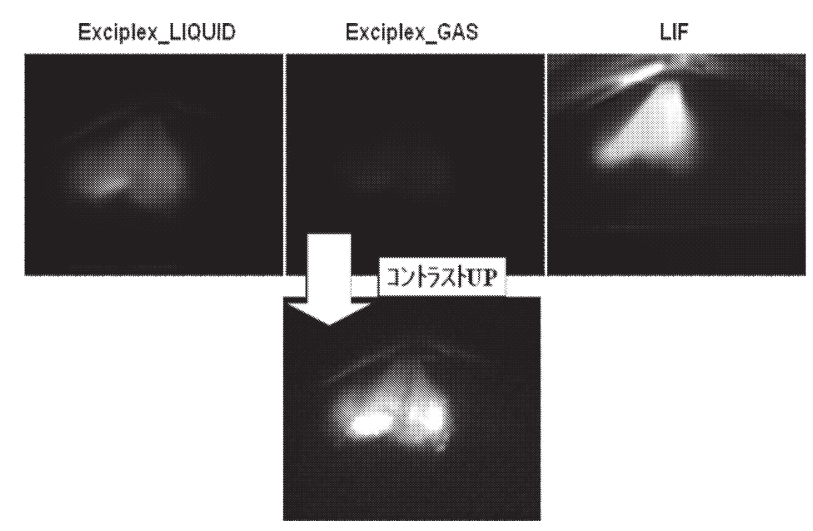

Fig. 13 Fluorescence images for liquid and vapor phases.

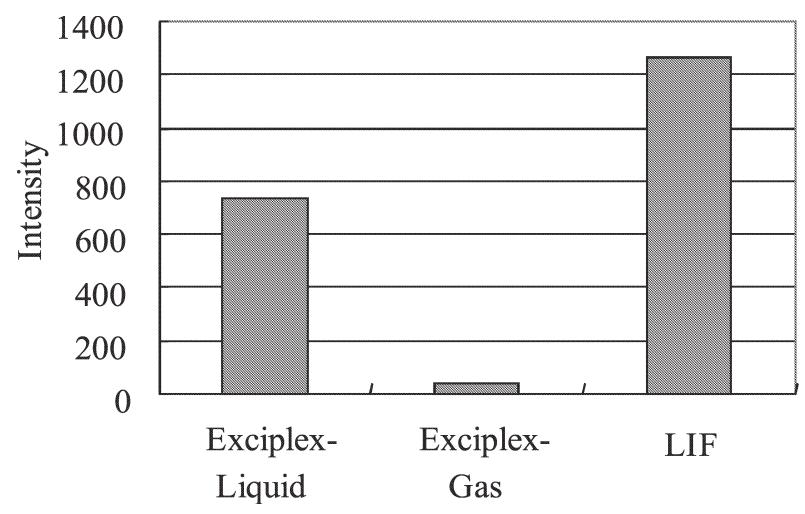

Fig. 14 Comparison of Mean fluorescence intensity of Exciplex and LIF.

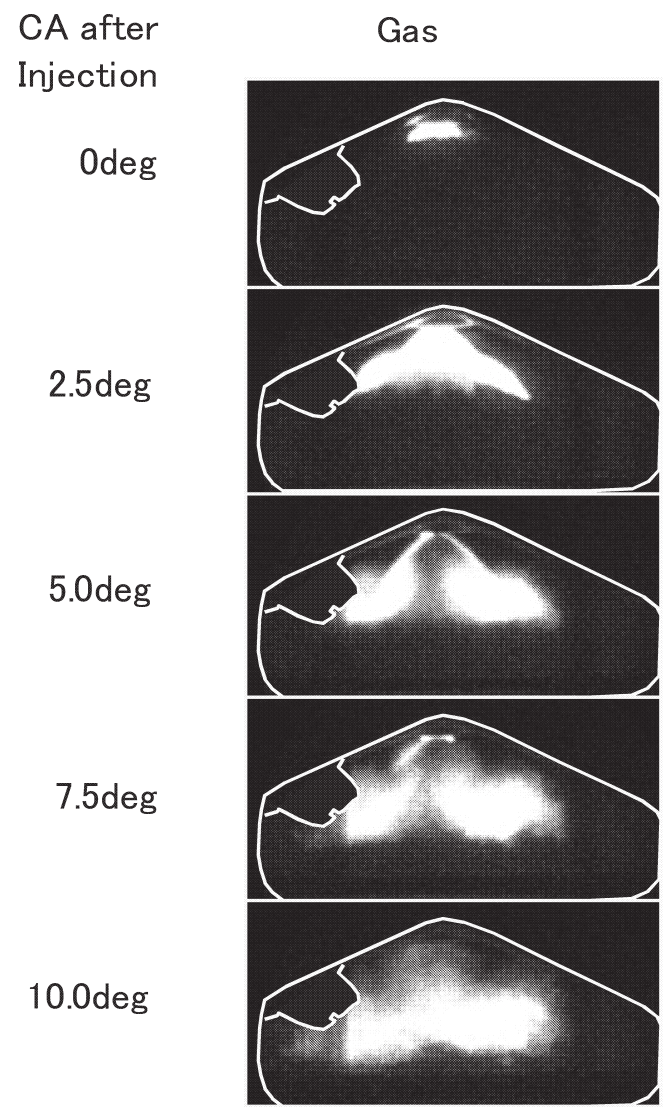

Liquid

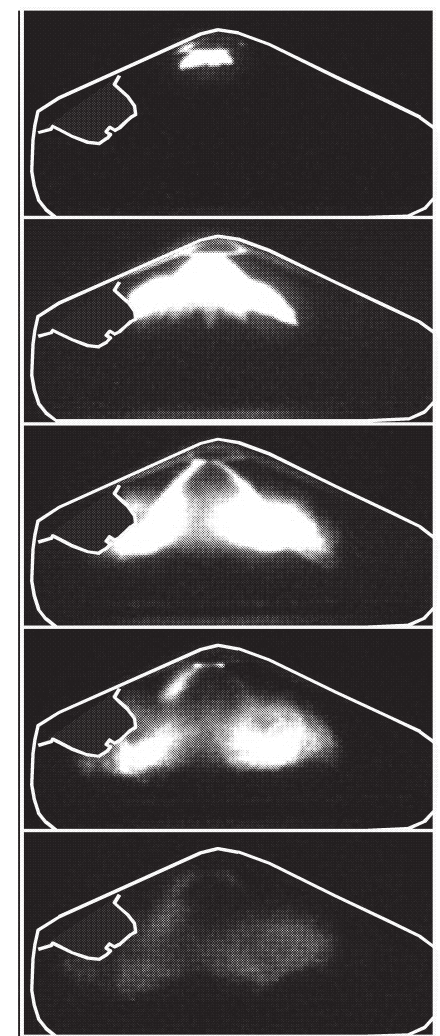

Fig. 15 Comparison of gas and liquid phase $1500 \mathrm{rpm}$ WOT, $\theta$ injend $45 \mathrm{deg}$. BTDC, Ti=0.35 ms. 


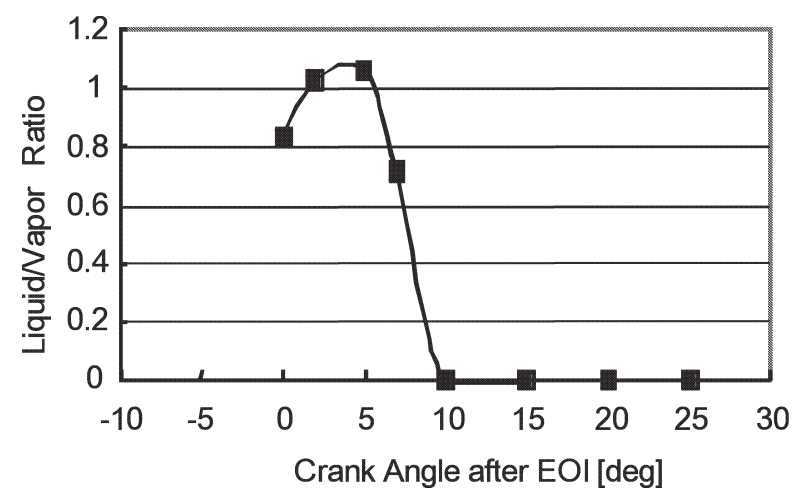

Fig. 16 Evaluation of Vapor liquid ratio.

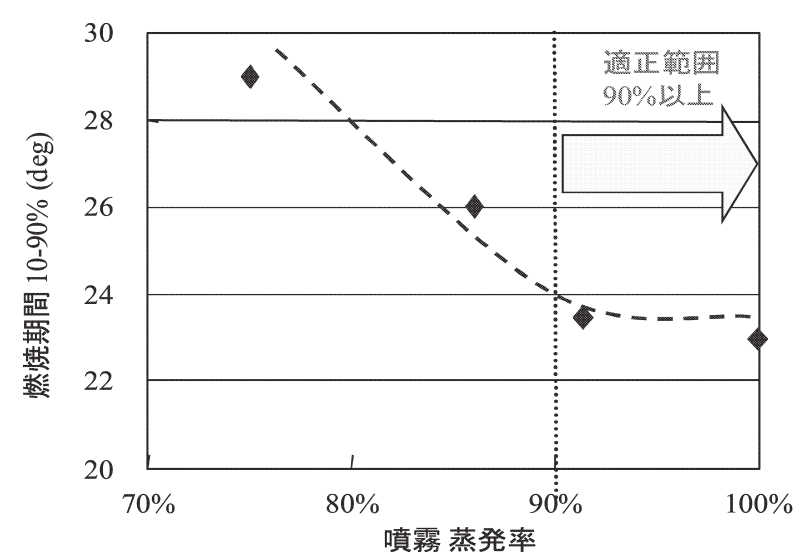

Fig. 17 Correlation between LIEF analysis and engine performance.

射後 $10 \mathrm{deg}$.では液相は観測されておらず，噴霧の蒸発 が急速に進行していることが分かる．燃料気相分布に対 する液相分布を指標化しインジェクタのノズル仕様や噴
射率, 運転条件違い等を解析する事と LIF 法による空燃 比計測結果を合わせ, 解析する事でエンジン諸元の決定 を行っている。

Fig. 17 に本解析で得られたインジェク夕噴霧蒸発率 と実機で得られた燃焼期間の相関を示す。 LIEF 法で得 られた気相面積に占める液相面積の割合を蒸発率と定義 している。また，燃焼期間は質量燃焼割合の 10～90\% の期間をクランク角で表している。罒より LIEF 法で得 られた気液相情報は主燃焼期間と強い相関があることが わかり，蒸発率が $90 \%$ 程度以上あれば等容度を損なわ ない高効率燃焼が得られると伺える。

\section{6. まと め}

LIEF 法をスプレーガイド直噴解析に導入し，気液相 分布が燃焼に与える影響を調べた結果，噴霧蒸発率と主 燃焼期間に強い相関が確認でき，最適噴霧仕様の指針設 定が可能となった。今後の直噴開発においては有効な解 析ツールの一つと考える。

今後さらに, HCCI などの高効率燃焼技術が求められ， 燃焼がス温度や EGR などの可視化計測の進化，開発へ の適用が望まれる。

\section{参考文献}

1) B.Leach, et al, Characterization of in-cylinder fuel distribution from an air-assisted fuel injection system using advanced laser diagnostics, SAE 2003-04-0088, (2003).

2 ) Horie, K., Goto, H., Kohda, Y., Ogawa, K., SAE 2004-01-2941 (2004) 